\title{
AN ANALYSIS OF CHINESE ECOMUSEUMS IN RELATION TO ECOMUSEUM THEORIES AND PRINCIPLES
}

\begin{abstract}
The main aim of this article is to reflect on the status of ecomuseums in China. There have been both ecomuseums and discourse about them for many years in China. However, despite the existence of academic literature on ecomuseums and therefore to the general theory of ecomuseums, from some points of view Chinese ecomuseums do not seem to be aligned with general ecomuseum principles. This article reflects both on how well ecomuseums in China fit the ecomuseum characteristics defined by the theory and, ultimately, on what we can learn from the Chinese experience. Our discussion is developed on the basis of both the existing academic literature and interviews conducted by the authors.
\end{abstract}

Keywords: Ecomuseum, place, community, China.

\section{Introduction}

The roots of the ecomuseum movement can be traced back to the $1960 \mathrm{~s}$, although the term écomusée, coined by Hugues de Varine, only came into use in $1971^{1}$. Early ecomuseum definitions suggest that the ecomuseum is a collective, a workshop extending over a territory that a population has taken as its own. It is not an end in itself; it is defined as an objective to be met. ${ }^{2}$ De Varine suggests that the label ecomuseum was nothing more than an opportunity to run

- Address for correspondence: Department of Sociology, Piazza dell'Ateneo Nuovo 1, 20126 Milano, Italy. Email: nunzia.borrelli@unimib.it.

- Address for correspondence: Department of Anthropology and Ethnology, 422 Siming Nan Road, 361005 Xiamen, China. Email: gerongling@xmu.edu.cn.

${ }^{1}$ See H. de Varine, Ecomuseum: The word and beyond, H. de Varine, Rethinking the museum concept, R. Rivard, Opening up the Museum or Toward a New Museology, R. Rivard, Museums and ecomuseums, K. Hudson, Museums of influence, K. Hudson, The Dream and the Reality, K. Hudson, Ecomuseums Become More Realistic, F. Hubert, Ecomuseums in France: Contradictions and Distortions \& P. Davis, Ecomuseums: A Sense of Place.

${ }^{2}$ P. Davis, Ecomuseums: A Sense of Place, p. 69. 
with new ideas, to be imaginative, to initiate new ways of working, even to be audacious ${ }^{1}$. However, since the term was coined in the $1970 \mathrm{~s}$, it has come to describe community-based heritage projects pursued within a defined geographical territory in order both to benefit local communities and to conserve and highlight - or increase - the value of the territory's tangible and intangible heritage resources ${ }^{2}$.

Today, the ecomuseum is regarded as a concrete expression of the school of thought known as New Museology that emerged in the 1960s and 1970s ${ }^{3}$. New Museology embraces the idea that museums can assist disadvantaged communities, becoming social actors in a process of social, cultural and environmental transformation ${ }^{4}$. In other words, in the 1960s, museum and heritage professionals understood that museums could be democratic and educational institutions for a community, thus distancing itselffrom the parameters of the aligned consumer society ${ }^{5}$. As Davis underlines, ecomuseums only exist thanks to the network of interactions between people and their particular physical, economic, social, natural and cultural resources. Moreover, ecomuseums can be considered one way of encouraging the local community to use both tangible and intangible heritage resources for sustainable development ${ }^{6}$.

But this view overlooks some of the new approaches taken by ecomuseums, which differ from traditional museums in how they involve the local community. As Rivard underlines, [w] hile traditional museums have frequently favored high culture, ecomuseums encourage local people to recognize the value of their place and promote participation.

The central aim of this paper is to examine whether or not ecomuseums in China fit the characteristics defined by the wider ecomuseum literature. We consider this topic particularly salient for a country like China, which is well known for the diversity of its tangible and intangible heritage resources. Ecomuseums in China may face challenges similar to those encountered by

\footnotetext{
${ }^{1}$ P. Davis, Ecomuseums: A Sense of Place, p. 69.

${ }^{2}$ See http://www.unesco.org/new/en/cairo/culture/tangible-cultural-heritage/: Tangible heritage includes buildings and historic places, monuments, artifacts, etc., which are considered worthy of preservation for the future. These include objects significant to the archaeology, architecture, science or technology of a specific culture and https://ich.unesco.org/en/what-is-intangible-heritage-00003: Intangible heritage includes traditions or living expressions inherited from our ancestors and passed on to our descendants, such as oral traditions, performing arts, social practices, rituals, festive events, knowledge and practices concerning nature and the universe or the knowledge and skills to produce traditional crafts, food and medicine heritage and digital heritage.

${ }^{3}$ As P. van Mensch, Towards a methodology of museology, p. 45, underlines the term new museology has been introduced at least three different times. It has been used by L. Benoist, Musées et muséologie, p. 29, in the early $20^{\text {th }}$ century. In 1980 the term muséologie nouvelle was introduced in France by A. Desvallées when he wrote an article on museology for the supplement of the Encyclopaedia Universalis. Finally, the term was introduced by P. Vergo, The New museology. The use of the term was always connected with the changing role of museums in education and in the society. According to J. Primo, Museus locais e ecomuseologica ..., the new museology conceives a broader field of action for museology in which, people becomes the relevant agent for the society transformation. Regarding New Museology refer to V. McCall \& C. Gray, Museums and the 'new museology'.

${ }^{4}$ See P. Davis, Ecomuseums: A Sense of Place, N. Borrelli \& P. Davis, How culture shapes nature ... .

${ }^{5}$ O. Navajas, New Common Perspectives for Ecomuseums ... p. 38.

${ }^{6}$ See P. Davis, Ecomuseums: A Sense of Place.

${ }^{7}$ R. Rivard, Museums and ecomuseums: questions and answer, p. 125.
} 
ecomuseums in the rest of the world, but they also have their own unique problems ${ }^{1}$. Not least of these is that, as part of its attempts to repopulate rural areas, the Chinese Central Government has decided to launch the $13^{\text {th }}$ FiveYear Plan, a nationwide tourism development project that aims to lift $17 \%$ of the country's impoverished population out of poverty by 2020. According to this plan, the China National Tourism Administration (CNTA) and the State Council Leading Group Office of Poverty Alleviation and Development expect that by 2020 , three million rural tourism businesses will be receiving two billion visitors annually, lifting two million of China's rural population out of poverty every year. The total income generated is estimated to reach over one trillion RMB Yuan, thus benefiting 50 million rural residents ${ }^{2}$.

In this context, ecomuseums are considered to be important tools for preserving cultural heritage and stimulating economic development in impoverished ethnic-minority regions, as well as for triggering forms of rural development ${ }^{3}$. As Nitzky (quoting Sofield and Li 1998) affirms: Tourism has become the focus for government-led ecomuseum initiatives for purposes of economic development, aiming to provide opportunities for the improvement of living standards for ethnic minority communities in the rural sector. Ecomuseums are in fact part of a larger movement across China to strengthen the conservation of China's heritage by linking it with tourism. ${ }^{4}$ Ecomuseums offer an important opportunity to create jobs for local communities. Through ecomuseums, local communities can help make their territories more attractive for internal and external tourism at the same time as taking care of the geographical area in which they live. In China, resource-related forms of economic development - such as tourism, modern ecological agriculture, and handicraft manufacture - are considered important ways of alleviating poverty in minority areas, and a possible corrective to the uneven rates of development between eastern and western, urban and rural areas ${ }^{5}$.

This paper argues that, although ecomuseums are widespread in China, they do not always seem able to achieve the goals that ecomuseums ideally pursue: i.e. the local community's leadership of and participation in governance processes, as well as the reinforcement of relationships among people and places. Our argument is based on semi-structured interviews with supervising experts, community leaders, and local stakeholders, photographic documentation of the ecomuseums, and document analysis (drawing on both academic and public policy documents) ${ }^{6}$. The paper is organized as follows: the next

${ }^{1}$ See C. Hu, Ecomuseums in Guizhou ..., , W. Nitzky, Community Empowerment at the Periphery?, W. Nitzky, Mediating Heritage Preservation and Rural Development ... \& W. Nitzky, Ecomuseums with Chinese Characteristics .... .

${ }^{2}$ See UNWTO, UNWTO and China Organize First World Conference on Tourism for Development.

${ }^{3}$ See W. Nitzky, Mediating Heritage Preservation and Rural Development .... .

${ }^{4}$ T. H. B. Sofield \& F. M. Li, Tourism Development and Cultural Policies in China \& W. Nitzky, Mediating Heritage Preservation and Rural Development ..., , p. 374.

${ }^{5}$ See J. Chio, A landscape of travel.

${ }^{6}$ We conducted individual interviews with Curator Wang He, Curator Cheng Yongjun and Curator Zhang Hui from Anji Ecology Museum; and Curator Luo Gang from Suoga Miao Ecomuseum. Moreover, we had 
section (Section 2) presents the concept of ecomuseums. Section 3 describes the history of ecomuseums in China. Section 4 describes ecomuseums as they currently exist in China. Section 5 discusses how ecomuseums in China fit the ecomuseum characteristics as defined by the academic literature. The last section (6) offers some conclusions.

\section{The Idea of the Ecomuseum: Theories and Principles}

The concept of the ecomuseum has been consolidated over the years and refined by various academic contributions seeking to identify its main features. Hamrin and Hulander listed 18 ecomuseum characteristics. But [t] his list makes little reference to the natural environment, to the need for distinctiveness within the geographical area, to past or contemporary environmental issues, to the role of living collections, or to the nature of the collections that ecomuseums care for ${ }^{1}$. Another attempt to define criteria for identifying ecomuseums was made by Davis who suggested the following: a territory with special heritage features, whose conservation and interpretation is carried out cooperatively and through partnerships; the empowerment and involvement of local community; a holistic approach ${ }^{2}$.

More recently the list of what have been called ecomuseum indicators was extended. Corsane recognized twenty one indicators and suggested that variations on these indicators might also be included ${ }^{3}$. Corsane with other scholar used these indicators to analyse ecomuseums in Italy. These authors underline that ecomuseums in Italy exhibit an array of characteristics that, taken together, serve to promote a holistic understanding of the preservation and management of cultural heritage ${ }^{4}$. Moreover, they specify that ecomuseums are, first and foremost, driven by local communities: the ecomuseum projects start by basing themselves on local communities' needs (principle 1) and encourage their participation through joint ownership and management (principles 2 and 3 ). As well as attending to local communities and to ecomuseums' management, the 21 principles $^{5}$ (concern how local people treat their territories, how holistic the integrated approach is, and to what extent there is continuous change (i.e. ecomuseums evolve over time, never remaining the same).

Three aspects of the ecomuseum approach are worth elaborating on further. First, the theoretical discourse on ecomuseums ${ }^{6}$ has benefitted from the intro-

\footnotetext{
informal conversations with 3 tour guides, 3 local stakeholders, and around 5 members of the local community from each of the ecomuseum sites we visited in Guizhou and Zhejiang. 5 employees from Guangxi ecomuseums were contacted and interviewed by phone. We also interviewed local experts: Professor Pan Shouyong from Minzu University of China, Professor Huang Ling from Baise University, Guangxi Autonomous Region, Dr. Jin Lu from Ningbo University.

${ }^{1}$ G. Corsane \& al., Ecomuseum Evaluation ..., p. 102.

${ }^{2}$ O Hamrin \& H. Mats, The Ecomuseum Bergslagen Falun ... \& G. Corsane \& al., Ecomuseum Evaluation ..., p. 102

${ }^{3}$ See G. Corsane, From 'outreach' to 'inreach' ... \& G. Corsane, Using ecomuseum indicators ... .

${ }^{4}$ See G. Corsane \& al., Ecomuseum Evaluation ... \& G. Corsane, Ecomuseums Performances in Piemonte ... .

${ }^{5}$ The 21 indicators become 22 in G. Corsane \& al., Ecomuseum Evaluation ... .

${ }^{6}$ See P. Davis, Ecomuseums: A Sense of Place, p. 20: In order better to understand the meaning of the term 'ecomuseum', it is important to explain the 'eco' prefix. The terms 'ecology' and 'economy' are derived from the
} 
duction of the concept of sense of place ${ }^{1}$. The added value of using this concept lies in its ability to emphasize ecomuseums' impact on relationships between community and place, and/or community and heritage. Such relationships are at the core of the ecomuseum concept.

People's sense of place consists of their feelings about a place, is often derived from an amalgamation of natural and cultural factors, and is dependent on human engagement with the physical place or environment ${ }^{2}$. Davis highlights that ecomuseums' main objective is to strengthen sense of place and to promote a positive and dynamic relationship between communities and the places where they live ${ }^{3}$. Refining the concept of sense of place, Hillier suggests that the development of a reflexive habitus ${ }^{4}$ - meaning the capacity to reflect on our cultural dispositions and develop new practices and behaviors towards our environment - is essential for creating positive relationships between nature and culture, humans and the environment. A reflexive habitus is thus important, in Hillier's view, for strengthening a sense of place ${ }^{5}$. Ideally, then, ecomuseum projects seeking both to reinforce the local community's sense of place, and to generate positive relationships between this community and their local area should do so by developing their reflexive habitus.

Second, despite the importance of the local community, territorial governance systems should also adopt a reflexive habitus in ecomuseum processes ${ }^{6}$. Territorial governance is considered to be the action of a government made up of many actors that operate at different geographical levels (local, national, international), and in different sectors (public, semi-public, private). Territorial governance should aim to pursue territorial development objectives, and to do so - via various different actors' contributions - using an integrated approach ${ }^{7}$.

Greek word oikos, which means a house or living place. In 1873 the German biologist Haeckel began to use the word in connection with the study of the interrelationships between organisms and the components making up their particular habitats, hence 'ecology'. Similarly, in ecomuseology the word 'environment' should be viewed holistically as embracing both natural and human aspects within a very intricate and interconnected system. This network encompasses both biophysical features and those elements which have been manipulated, modified or constructed by people, as well as intangibles such as economic, social, cultural and political dimensions which are also an integral part of our environment.

${ }^{1}$ See P. Davis, Ecomuseums: A Sense of Place \& N. Borrelli \& P. Davis, How culture shapes nature ... .

${ }^{2}$ See Y.-F. Tuan, Space and place ... \& A. Buttimer \& D. Seamon, The human experience of space and place.

${ }^{3}$ See P. Davis, Ecomuseums: A Sense of Place.

${ }^{4}$ Habitus, a set of structures and habitual ways of understanding characteristic and constitutive of a society or a group, can be changed by new experience, education or training. In other words it tends to perpetuate - to reproduce - itself, but it is also subject to change. See P. Bourdieu \& L. J. Wacquant, Réponses: pour une anthropologie réflexive, p. 133.

${ }^{5}$ See J. Hillier \& E. Rooksby (eds.), Habitus: A sense of place.

${ }^{6}$ We are using the term ecomuseum processes because ecomuseums are supposed to change over time, and thus not remain the same. It is therefore helpful to consider them not as comparatively static institutions - as might be suggested by the term museum - but rather as a set of constantly-evolving activities that take place over a given geographical area. See G. Corsane et. al., Ecomuseum Evaluation ... .

${ }^{7}$ On territorial governance and the importance of an integrated approach see J. Coaffee \& P. Healey, 'My voice: My place' ..., G. Cars \& al. Urban governance, institutional capacity and social milieu, D. Stead \& E. Meijers, Spatial Planning and Policy Integration ... . An approach is integrated (or holistic) when it involves 
According to J. Coaffee and P. Healey governance is not limited only to specific events or processes about which decisions are made; it also involves the cultural system of a place. Hence governance capacity also lies in the ability to change the cultural system - the ability to redefine discourse and practices through dialogue, interaction and communication. The implementation of joint learning processes in order to re-define cultural systems requires the participation of territorial experts, technicians, stakeholders and ordinary inhabitants, and ensures that the approach is integrated ${ }^{1}$.

Third, the purpose of the ecomuseum is not only to preserve significant places but also to engage local communities in processes whereby they learn to conserve their local area. Thus ecomuseums should promote a culture of territorial governance that provides opportunities for self-governance, as well as an idea of governance that includes a wider range of local actors ${ }^{2}$. In this scenario, the state is just one of the actors engaged in conserving the local environment; it is not the only actor involved. Ideally, the state should work together with local communities, raising awareness of the important role that they themselves can play as guardians of the territory.

In sum, ecomuseums should, ideally, encourage a democratic territorial governance culture and the empowerment of local people ${ }^{3}$. While many of the ecomuseums developed during the 1980s and the early 1990s were often used purely as agencies for promoting local tourism, later ecomuseums have promoted their own values of encouraging local community leadership and conserving tangible and intangible local resources ${ }^{4}$. These later ecomuseums are based on a form of territorial governance that involves a wide range of actors, stimulates the awareness of local people, and aims to foster both development as well as a more democratic governance system by increasing the leadership and participation of the local community. At the same time, these ecomuseums are intended to reinforce the relationships between local people and their environment, thus affirming a sense of place.

\section{The History of Ecomuseums in China: The Three Generations}

Despite certain commonalities between ecomuseums in different communities and places within China, most scholars agree that Chinese ecomuseums can be categorized into three generations ${ }^{5}$. In this section, we present Chinese

\footnotetext{
different sectors - and is thus not restricted to one single sector. The benefits of such an approach are thought to amount to more than the benefits of acting within each sector separately; this is why it is also referred to as holistic.

${ }^{1}$ See J. Coaffee \& P. Healey, 'My voice: My place'.... .

${ }^{2}$ See T. Bennett, Civic laboratories ... .

${ }^{3}$ On the community-based heritage project see also the relevant contributions of F. Berkes, Evolution of co-management ... , T. Hahn, P. Olsson, C. Folke \& K. Johansson, Trust-building, knowledge generation and organizational innovations ..., P. Olsson, C. Folke, V. Galaz, T. Hahn \& L. Schultz, Enhancing the fit through adaptive co-management ..., R. Plummer, D. Armitage \& R. de Loë, Adaptive comanagement ..., L. Schultz, C. Folke \& P. Olsson, Enhancing ecosystem management ... \& F. Westley, O. Tjornbo, L. Schultz, P. Olsson, C. Folke, B. Crona \& Ö. Bodin, A theory of transformative agency ... .

${ }^{4}$ See also P. Davis, New Museologies and Ecomuseums.

${ }^{5}$ See D. Su, Zhongguo Shengtai Bowuguam de Daolu \& S. Pan, Di San Dai Shengetai ... .
} 
ecomuseums according to this diachronic classification, describing the academic consensus as to the character of each of these three generations of ecomuseum, using selected case studies as examples. Nonetheless, it should be noted that not all ecomuseums reflect the characteristics of these phases, and that each ecomuseum's distinctive features should be determined by independent ethnographic fieldwork.

There are currently 27 ecomuseums in China. If we count the members of the Anji County ecomuseum group individually, the number rises to 67. Table $1^{1}$ is a list of all ecomuseums in China; the year in which they were established is listed under the column headed Opened. The numbers in the first column of Table 1 correspond to those on the map in Figure 1, which presents Chinese ecomuseums' geographical distribution.

\subsection{The First Generation}

The concept of ecomuseum was introduced into China in 1986 by $\mathrm{Su}$ Donghai, who has been called the Father of Chinese Ecomuseums ${ }^{2}$. In 1994, the annual meeting of the International Committee for Museology (ICOFOM) was held in China, and Su met John Aage Gjestrum, a Norwegian museologist. With the help of Gjestrum, Su and his colleagues successfully applied for funds from both the Norwegian and Chinese governments to initiate the first ecomuseum project: the Suoga Miao Ecomuseum. The project was launched in 1995 and opened in 1998 in the territory of Liuzhi Prefecture and Zhijin County in Guizhou Province ${ }^{3}$.

In this paper, we use the Suoga Miao Ecomuseum as a case example of the first-generation ecomuseums. The Suoga Miao Ecomuseum is characterised by the living presence of the Longhorn Miao minority group, a small branch of the Miao people. The population of Longhorn Miao is about 4000, inhabiting 12 adjacent mountain villages. A documentation centre was built to document information about their customs, beliefs, rituals and memories. There is also an exhibition centre showcasing everyday objects, such as traditional clothes and tools, used by the Miao people. The documentation centre of the Suoga Miao Ecomuseum is located in Longga, one of the 12 villages.

The Suoga project was included in the 1995-1996 Sino-Norwegian Cultural Exchange Program agreed in the presence of Norwegian King Harald $\mathrm{V}$ and the then Chairman of China Jiang Zemin in October 1997 in Beijing ${ }^{4}$. Following the same program, three other ecomuseums were established soon after the Suoga Miao Ecomuseum in Guizhou province. They were the Zhenshan Buyi Ecomuseum (opened in July 2002), the Longli Ancient Town Ecomuseum (opened in October 2004), and the Tang'An Dong Ecomuseum (opened in June 2005). These later ecomuseums aimed to preserve the living traditions of three different ethnic groups: the Buyi, Han and Dong peoples

\footnotetext{
${ }^{1}$ For Table 1 and Fig. 1-5 see pp. 145-151.

${ }^{2}$ See W. Nitzky, Mediating Heritage Preservation and Rural Development ... , p. 373.

${ }^{3}$ See D. Su, Zhongguo Shengtai Bowuguande Daolu.

${ }^{4}$ See D. Su, Zhongguo Shengtai Bowuguande Daolu.
} 
respectively. All four of these Guizhou ecomuseums are considered part of the first pioneering generation of ecomuseums in China.

These ecomuseums were based on the China ecomuseum practice guidelines, known as the Liuzhi Principles. Liuzhi Principles were drawn up in 2000 by both Norwegian and Chinese museum experts ${ }^{1}$. They identify local villagers as the main owners of their culture and recognize the importance of local communities' participation in ecomuseum governance processes. For $\mathrm{Su}$, they were the products of governmental needs to protect cultural diversity plus professional passion for [ecomuseum] ideology ${ }^{2}$.

\subsection{The Second Generation}

The second-generation ecomuseums are those that follow what is known as the 1+10 Model of Ethnic Ecomuseum developed in Guangxi Zhuang Autonomous Region (see Fig. 2) by the Guangxi Culture Department, domestic museum experts, and ethnologists from Guangxi Minzu Museum ${ }^{3}$. In 2002, a group of cultural affairs officers from Guangxi Autonomous Region were led by the Department of Culture on a field trip to survey the ecomuseums in Guizhou. Through observations, as well as lectures and guidance from museum experts, the Guangxi Department of Culture initiated its own exploration of ecomuseum development. Compared to the four pioneering ecomuseums in Guizhou, the development of the ecomuseums in Guangxi was more interventionist. Instead of having one documentation centre in the community to make a record of local resources, each ecomuseum has an exhibition centre to make the visitors' experience more museum-like ${ }^{4}$; indeed, visitors report that the exhibition centre feels like a traditional museum building. The construction of the exhibition centres was mostly financed by the government of Guangxi Zhuang Autonomous Region, though the prefectures and counties also contributed a portion of the funding. On the other hand, the Guangxi Minzu museum also set up a special fund for the Cultural Memory Project, to which each ecomuseum could apply for the purpose of documenting resources so as to preserve cultural memory. Each ecomuseum functions as one of the Research Stations of Guangxi Minzu Museum, and curators from the central museum are not only responsible for supervising the local ecomuseums; they also treat the surrounding ten ecomuseums as their ethnographic fieldwork sites. Concurrent to the establishment of the Guangxi ecomuseums, Yunnan province in the South West and Inner Mongolia in the North West also established a few ecomuseums (see Table 1).

\subsection{The Third Generation}

The establishment of the third generation of ecomuseums was promoted by China's State Administration of Cultural Heritage (SACH), with the Anji

\footnotetext{
${ }^{1}$ See C. Hu, Liuzhi Yuanze yu Minzu Wenhua Baohu.

${ }^{2}$ D. Su, Zhongguo Shengtai Bowuguande Daolu, p. 15.

${ }^{3}$ See W. Wu, Cong Minzu Shengtai Bowuguan ... .

${ }^{4}$ See D. Su, Zhongguo Shengtai Bowuguan de Daolu, p. 16.
} 
Ecology Museum in Zhejiang Province as its first project. It comprises a network of ecomuseums, including 1 central museum, 13 theme museums and 26 village museums ${ }^{1}$ (see Fig. 3), each consisting of a cultural exhibition hall.

The project was initiated in 2008 and opened in 2012. It is the first to be located in the developed eastern coastal area of China. The Anji Ecology Museum is financially better-off compared to earlier generations of ecomuseum $^{2}$ and is characterised by less ethnic diversity. The region is mainly populated by Han Chinese ${ }^{3}$. Therefore, instead of ethnic cultural diversity, ecomuseums in Anji focus more on the nature/human balance and environmental integrity. Land topography, agricultural products, and modern industries are seen as being just as important as cultural traditions. This may be the reason why the ecomuseum in Anji is named Anji Ecology Museum ${ }^{4}$, instead of Anji Ecomuseum.

\section{The Synchronic Analysis: Observing Chinese Ecomuseums through the Lens of Ecomuseum Principles}

In this section we present a synchronic analysis of the three generations of ecomuseums. We take into account ecomuseum principles, paying particular attention to the role of the local community in ecomuseum territorial governance processes and to local actors' awareness of their territory's value. On this last aspect, we examine the potential conflicts between tourism development and the recognition of heritage value.

\subsection{Actors Involved in Ecomuseum Processes: Strong Public} Administration, Weak Local Community

Despite the first generation of ecomuseums being based on the SinoNorwegian agreement and the Liuzhi Principles, this generation is characterized by very low levels of leadership among both the local community and local public officials. The Suoga ecomuseum governance process was dominated by experts, i.e. people very familiar with ecomuseum theory because they were directly involved in the Sino-Norwegian agreement.

According to the Liuzhi Principles, the director should have been one of the local Miao villagers, but because none of the villagers was able to pass the examination to become director ${ }^{5}$, the ecomuseum director appointed was a civil servant. Su attributes this failure to the museum's remoteness and the local

\footnotetext{
${ }^{1}$ The number changes according to whether there are new members joining, or old ones closing down. In 2014 a new theme museum was added to the list.

${ }^{2}$ See S. Pan, Shengtai Bowuguan ji qi zai Zhongguo de Fazhan ... .

${ }^{3}$ Only one of these 40 ecomuseums is an ethnic minority village, belonging to the She people.

${ }^{4}$ Professor Nelson Gruburn reminded the authors to notice this term and its significance during a field trip to Anji in Aug. 2015.

${ }^{5}$ People who wish to apply for the position must pass an examination sponsored by the respective institutions, such as the prefectural department of culture. The examinations, similar to the Chinese Civil Service Examination, usually include sections such as an administrative professional ability test and argumentative essay writing. Villagers from the local communities could not pass the examination. Most of them had barely finished junior high school due to their poor economic conditions. Only a few were hired as coordinators. Instead, the prefecture government assigned staff members as acting deputy directors. See also J. Chio, A landscape of travel.
} 
people's scant knowledge of ecomuseums ${ }^{1}$. He argues that villagers need to be educated to understand the ecomuseum concept much better, while museum experts need to improve how they give advice. As the current deputy director of the Suoga ecomuseum, Luo Gang, underlined, it is just as hard to increase the villagers' enthusiasm and their ability to be part of the ecomuseum, as it is to change their unhygienic habits in order to develop the hospitality industry. In his view the only thing to do is to wait for the next educated generation. Local schooling improved significantly thanks to the government's ecomuseum funds and its poverty alleviation budget, but according to Luo Gang this improvement was insufficient.

To sum up, in the first generation of ecomuseums there was neither any leadership by nor any involvement of the local community; local public officials (for example people working in regional or county government) had a marginal role; and everything was in the hands of the experts who had promoted the Sino-Norwegian agreement.

The second-generation Guangxi ecomuseum employs a number of local managers from the Guangxi Zhuang Autonomous Region. These managers were trained by experts: the ethnologists from the ecomuseum's central institution, the Guangxi Minzu Museum. This ecomuseum is composed of 11 stations, and each station operates as one of the Guangxi Minzu Museum's Research Stations. Curators and ethnologists from the Guangxi Minzu Museum teach the local managers how to preserve local resources, and the villagers can become part-time researchers at the Guangxi Minzu Museum. Sometimes local people - usually village heads or schoolteachers - are tasked with taking care of the exhibition centres. According to information collected during our interview with a curator and our conversation with local stakeholders, most villagers participate in the project simply as construction workers or cultural performance presenters during festivals and other big events.

The Guangxi Zhuang Autonomous Region's ecomuseum allows the participation of some local stakeholders, but not of the local community. The local community remains more a potential user of the ecomuseum's services rather than a protagonist of the ecomuseum process.

Anji Ecology Museum - part of the third generation - still adopts a general top-down territorial governance approach. The director of SACH, Shan Jixiang (active from 2002 to 2012), initiated the Anji project himself. Some university professors as well as some curators from the Anji County Museum are on the supervisory committee. In the Anji ecomuseums, different local businesses are also involved: farmers, owners of modern industrial enterprises such as furniture factories, and bean food producers are integrated as part of the ecomuseum system. Because it encompasses local people's livelihoods, Anji Ecology Museum is a more open ecomuseum than those established earlier.

Each of the Anji ecomuseums has three kinds of paid position: one director, one curator, and up to three community residential contacts. It became evident from our fieldwork that all of the employees in these positions are local: the

${ }^{1}$ See D. Su, Zhongguo Shengtai Bowuguan de Daolu. 
directors and curators are mostly village leaders, members of the local elite, or - in some cases - factory owners.

In the third generation of ecomuseum, even though local people and local stakeholders are more involved than before, the local government is definitely still the strongest actor and the management system remains top-down. A comparison of the three generations shows that the first generation is characterized by a relatively clear divide between the local community and ecomuseum expertise: the governance system is in the hands of experts. In the second generation of ecomuseums, the problem of weak community activation is recognized but only partially resolved, and members of the local community remain at best users of ecomuseum services. In the last generation of ecomuseums, because these ecomuseums have been established in developed areas of the country where people are more educated, some efforts have been made to involve local people.

\subsection{Awareness of the Territory's Value}

George Henri Rivière declared that ecomuseums should be for local people, acting like mirrors reflecting their imagery of themselves and the places they inhabit ${ }^{1}$. This means that ecomuseums should stimulate local communities' awareness of place and of the value of preserving heritage. Ecomuseums should allow local people both to understand their heritage and to conceive themselves as an integral part of this heritage. In other words, they should allow the local community to feel like guardians of their local area and therefore be protagonists in its improvement.

In Suoga (the first generation) there is a documentation centre and a small exhibition room displaying tangible and intangible resources, as well as a visitor map (see Fig. 4) showing the localities where different cultural activities take place. It is hard to say that the local people are aware of their territory's value. Only very few local villagers, mostly young females, participate in activities presenting heritage to tourists, and they do so in very restricted ways. In the village of Longga, only approximately 20 young girls are engaged in tourist activities and they do so in only two main ways. First, they dress up in traditional clothing and headdresses for tourists (see Fig. 5). Second, they perform traditional dances in the documentation centre's central plaza. The traditional longhorn headdress has been radically exaggerated since the ecomuseum opened in order to please tourists, photographers, and even anthropologists. Traditionally, a local woman's headdress was braided from her own hair together with her mother's and grandmother's, symbolizing the maternal inheritance lineage. Information collected during fieldwork indicates it is oversized and exaggerated with a mass of yarn purely to attract the attention of visitors. What is striking about the Suoga case is that it reveals the risks of local heritage valorization when it has to achieve the objectives of tourism development.

\footnotetext{
${ }^{1}$ See G. H. Rivière, The Ecomuseum: An Evolutive Definition.
} 
The dangers lie in the commodification of intangible heritage when it is evaluated primarily according to its market value ${ }^{1}$. In the case of Suoga, the presence of the ecomuseum prevents the real meanings of local customs and local traditions - which have been kept alive by ecomuseum practices - from being forgotten. At the same time, the distorted use of local customs - like the wearing of traditional longhorn headdress - indicates that the local communities are not aware of their role in preserving heritage value, and do not feel like guardians of their heritage; instead, they market it.

In Guangxi (the second generation), the ecomuseum helped enhance local conditions by improving infrastructure, including roads, sanitation systems, and networks for supplying electricity and potable water. Like Suoga, the Guangxi Ecomuseum has an interest in enhancing the territory's heritage value by preserving both tangible and intangible heritage, but it is equally indifferent to the local community's leadership. At the time the ecomuseum was launched, nothing was being done to protect or enhance the local heritage, and its sites were not selected based on existing cultural economies.

Since the establishment of the Guangxi project, tourism has become one of Chinese ecomuseums' principal objectives. Villages with potential for tourism development were selected for the Guangxi ecomuseum project list, following which the tourism economy in many of these communities grew significantly. The creation of local tourism markets has helped secure more government funds for local infrastructure. In general, there was an effort among these ecomuseums to give certain villages a make-over to render them more attractive. This kind of practice enables the ecomuseums to attract tourists and also to improve local villagers' income ${ }^{2}$, but not really to make local communities aware of their territory's value.

In the Jing Ecomuseum in Dongxing, for example - one of the Guangxi Projects - an exhibition hall was established in Wanwei village in 2009 to exhibit the Jing people's ethnic culture using artifacts and pictures. The hall has been seen as an alien space by most local villagers because it is only visited by tourists. Local people seldom enter it; they see it as a space detached from their cultures and daily lives because it does not involve them directly and is owned by the government, academic institutions, and tourist agencies (information collected during phone conversations).

The Anji Ecomuseum's projects were initiated with money raised from local companies or villages. Some of its exhibition halls were built to serve primarily economic functions. It was only later that the owners requested that their constructions be listed as ecomuseums. Their applications were approved if the halls satisfied the county museum committee's criteria, among which were having appropriate facilities (e.g. access roads, tour guides) and exhibiting the right artefacts (e.g. local products such as bamboo folding fans). If

${ }^{1}$ See C. Goulding, The commodification of the past ..., R. Shepherd, Commodification, culture and tourism \& T. H. H. Nguyen \& C. Cheung, Authenticity and commodification of Hong Kong heritage tourism.

${ }^{2}$ In 2007, after being listed as ecomuseums for only one to three years, the per capita income of four of those ecomuseum villages - in Jiuzhou, Longsheng, Nandan and Napo - had doubled. See S. Pan, Shengtai Bowuguan ji qi zai Zhongguo de Fazhan ..., , p. 27. 
successful, the museum could call itself an ecomuseum, obtain professional architectural design support, and apply for additional funds from the local government.

The different ecomuseums belonging to the Anji Ecomuseum perform very differently. For example, the Yutiao and Zhangwu are two neighboring villages both of whose inhabitants' livelihoods consists in making bamboo folding fans. However, the Yutiao ecomuseum is themed around classic painting and calligraphy, while Zhangwu ecomuseum is themed around fan-slat manufacturing and painting. The exhibition hall at Yutiao is more like an art studio. It only attracts local peasant artists and art lovers - a very small group of participants. Meanwhile the main area of Zhangwu ecomuseum is a factory and commercial street - the main street of the village. Most of the local craftspeople making fan slats, together with their family members, naturally become participants in the village ecomuseum, delivering workshops for visitors.

Many of the Anji ecomuseums serve economic purposes: in order to attract visitors to areas where they will spend money on local products, some exhibition halls are located in community marketing areas such as tea trading centres or bamboo product transportation harbours. Our fieldwork indicated they can also act as trading centres themselves.

The third-generation Anji Ecology Museum focuses more on the natural, cultural, social, and ecological assets of the villages themselves than do the ecomuseums from previous generations. The example of the Anji Ecology museum demonstrates how ecomuseum practice in China has gradually grown up to achieve its initial goals of preserving tangible and intangible heritage, awakening the local community's self-cognition through the governance process and raising their awareness of their territory's value'.

From what we have shown up to this point, it is possible to conclude that ecomuseums' presence in China certainly creates benefits for the places in which they are located, because it prevents tangible and intangible heritage from being abandoned, as has unfortunately happened often in China in the past. At the same time, however, heritage conservation practices are not able to facilitate the local community's leadership or to trigger awareness of place value because their prevailing intention is to make local heritage attractive for tourists.

To sum up, among the first two generations of ecomuseums, even though there are efforts to preserve local heritage, we cannot say that local communities are aware of their place value or have started to feel like guardians of their own territory. Among the last generation of ecomuseums, however, because they are located in a developed area and are themed around village livelihoods, villagers are more aware of their place value. Nonetheless the main reason for these ecomuseums' development definitely remains the enhancement of local heritage for tourism.

\section{Assessing the Chinese Ecomuseum Using Ecomuseum Theories}

The main aim of this paper has been to discuss to what extent Chinese

\footnotetext{
${ }^{1}$ See N. Graburn. \& L. Jin, Tourism and Museums in China \& S. Pan, Self-cognition and Self-education at ecomuseums....
} 
ecomuseums are able to achieve the goals that ecomuseums theoretically pursue, i.e. the local community's leadership in the governance process, and the reinforcement of relationships between people and place ${ }^{1}$. As highlighted in section 2, at the basis of ecomuseum practice lies an effort to consolidate relationships between people and place, which can only be achieved by working on the cultural system, or on what Bourdieu and Wacquant called habitus ${ }^{2}$. Ecomuseums should operate at the level of habitus, helping to raise local people's awareness of the heritage value of the place where they live and what they can do to protect and enhance it ${ }^{3}$.

Judging by what we have said in previous sections, it seems that the ecomuseum practices carried out in China are not very well aligned with these goals. The Chinese ecomuseums are characterized by a low level of local community leadership and top-down territorial governance. Even though thanks to the Sino-Norwegian agreement - the Chinese experts were aware of the importance of local community leadership in ecomuseum governance, no good strategies for making the local community more active have been developed. The ecomuseums are mostly managed by experts from academic institutions, which does not ensure the implementation of a holistic approach. Moreover, the documentation centres usually present the generalized past and are designed by experts to present traditional ethnic characteristics ${ }^{4}$. This lack of local voices impedes the local villagers from defining and understanding the full value of their territory, and ultimately from playing an active part in heritage preservation practices.

The low levels of leadership among the local communities causes not only poor cultural awareness, but also a tendency to re-museumize the ecomuseums, which is at odds with the idea that the ecomuseum should be a dynamic process. We can see this re-museumizing tendency by observing the changes in ecomuseum practices over time. The first-generation ecomuseums in Guizhou made only a weak attempt to include entire living spaces within the territory of the ecomuseum. Meanwhile the Suoga Miao Ecomuseum included all of its 12 villages within its territory from the outset, although only Longga village was actively involved.

Starting with the ecomuseums in Guangxi, the second- and third-generation museums established exhibition halls instead of documentation centres. Tourists are drawn to these exhibition halls to view cultural artifacts instead of visiting local places. The exhibition halls are much more like traditional museums, and they need more professional care. This may be one of the reasons why local people find the ecomuseum space detached from their cultures and daily lives, and regard outside professionals or government officials as those responsible for taking care of the exhibition spaces.

\footnotetext{
${ }^{1}$ See G. Corsane \& W. Holleman, Ecomuseum: A Brief Evaluation, P. Davis, Ecomuseums: A Sense of Place, P. Davis, New Museologies and the Ecomuseums, G. Corsane \& al., Ecomuseum Evaluation ..., G. Corsane \& al., Ecomuseum Performance ... \& N. Borrelli \& P. Davis, How culture shapes nature ... .

${ }^{2}$ See P. Bourdieu \& L. J. Wacquant, Réponses: pour une anthropologie réflexive, p. 133.

${ }^{3}$ See N. Borrelli \& P. Davis, How culture shapes nature ... .

${ }^{4}$ See J. Chio, A landscape of travel.
} 
Notwithstanding this tendency, the last few years have seen the spread of the so-called Nong Jia Le [Happy Peasant Houses] which help strengthen the local population's participation. The Nong Jia Le are very popular in many ecomuseum villages ${ }^{1}$. They allow villagers to run guestrooms and restaurants serving local foods in their own houses. The dishes are mostly prepared from vegetables and fruits grown in the villages themselves as well as meat from locally-farmed animals. A Nong Jia Le restaurant will rely on several other families in the neighborhood to supply its food. The hosts usually perform traditional ethnic songs and dances to entertain guests. Some hosts also invite guests to experience farming activities on their lands.

Although these activities strengthen the local people's involvement, they are still strongly oriented towards economic value alone. In other words, the Happy Peasant Houses do not help make the local community more aware of their territory's heritage value, they only help them understand the commercial potential of certain local resources. This does not mean that the Happy Peasant Houses are devoid of value; rather, it means that the central purpose of an ecomuseum project, i.e. to involve local communities in order to make them more aware of their territory's value, is unfulfilled in these cases as well.

The idea of the ecomuseum was brought into China to guide local communities in identifying the cultural value of local sites, to make them protagonists of the governance system, and to seek ways to create sustainable development. After nearly twenty years, and over the three generations of ecomuseums, these aims have been only partially achieved in local communities.

\section{Conclusions: Learning from Chinese Experiences}

In China, the local community's role is still limited in ecomuseum projects. Its marginalization was obvious in the first and second generations of ecomuseums, and it is still apparent in the third generation. While national institutions such as $\mathrm{SACH}$, experts, professors and local governments play major roles in terms of funding, supervising and - most importantly-managing all ecomuseum projects in China, local community members are frequently recruited not at the managerial level, but mostly as users or curators of the museums.

During all three historical stages, it appears that ecomuseums in China were projects initiated by outsiders for different kinds of reason. None of the ecomuseums ever stemmed from local community desire, nor were local communities ever consulted in the early stages of any ecomuseum planning. As a result, one of the ecomuseology principles is unfulfilled in China.

Moreover, because of its very marginal role, the local community has not gained awareness of the value of its territory. In some cases, where ecomuseum activities have been introduced directly into tourist circuits, members of the local community realize the economic value of their local resources but rarely become truly aware of their cultural value.

\footnotetext{
${ }^{1}$ See J. Newton \& A. Franklin, Delivering sustainable communities in China ... .
} 
Local communities' low levels of leadership and weak awareness of their territory's value affects not only ecomuseums, but also other projects in China, where the degradation of the natural environment and the lack of community involvement in its preservation have become common concerns. National projects have been launched at significant heritage sites in order to combat these challenges. Documents like the Principles for the Conservation of Heritage Sites in China, known as the China Principles, issued by ICOMOS China (2002), have also been published for this reason. The China Principles were drafted through collaboration among professionals and experts from the $\mathrm{SACH}$, the Getty Conservation Institute (GCI), the then Australian Heritage Commission (AHC), as well as site managers from Mogao Grottoes and Chengde's Shuxiang Temple ${ }^{1}$. Apart from architectural conservation, and appreciation of the aesthetic, historical and research values of heritage sites, the China Principles also introduced the ideas of site master planning, visitor capacity, and governance to the Chinese cases ${ }^{2}$. Their emphasis on governance was highlighted as an important innovation at the time ${ }^{3}$. In the revised edition enhancement as well as preservation, social characteristics, intangible resources, the inclusion of relevant stakeholders, and public involvement are all clearly reinforced and considered fundamental for the conservation and improvement of place ${ }^{4}$. With this study we have therefore tried to tackle a problem already considered in the Chinese ICOMOS principles, namely that heritage can only be preserved properly when the local residents become aware of the place's value and conscious guardians of their own territory.

Despite the fact that ecomuseums in China have neither enabled the local community's full involvement by adopting an open and inclusive form of governance which could have facilitated an integrated approach - nor made the local community aware of these territories' value - it cannot be denied that they have made it possible to safeguard local heritage and improve the local population's economic conditions, helping alleviate poverty.

Poverty alleviation is a major impetus for initiating ecomuseum projects in China; increased tourism is seen as a way of generating income for local communities. Despite resulting in some positive effects due to the channelling of significant investments into degraded areas, the decision to include ecomuseum projects among those able to reduce poverty among the local population has also had some negative repercussions.

Alleviating poverty can be considered an ambitious goal for an ecomuseum project, one that would be too difficult to accomplish. In other words, if poverty alleviation is one of the main reasons why ecomuseums were initiated, then it makes sense that there would be significant outside intervention since alleviating poverty is such a challenging goal to achieve.

\footnotetext{
${ }^{1}$ See N. Agnew, M. Demas \& S. Sullivan, The development of the China Principles ..., p. 11.

${ }^{2}$ See GCI, China Principles - Application at Maogao Grottoes.

${ }^{3}$ See N. Agnew, M. Demas \& S. Sullivan, The development of the China Principles ..., p. 19.

${ }^{4}$ See N. Agnew, M. Demas \& S. Sullivan, The development of the China Principles ..., p. 26 \& ICOMOS China, Zhongguo Wenwu Guji Baohu Zhunze.
} 
The Chinese ecomuseum cases could thus help us rethink the power of funds. In China there is a copious amount of government funding for developing ecomuseums when they are associated with poverty alleviation. Although it is important to alleviate poverty in order to gain support from state funds, doing so may also make local people accept the legitimacy of top-down governance. It thus can impede local community empowerment because there is no space for individual initiative; rather, activities are programmed from the top-down. Moreover, the empowerment of local communities can also be threatened by competition from external entrepreneurs with big capital. The decisions that these entrepreneurs make may override the preferences of local communities.

The risk of this approach is that the ecomuseums' declared goals will be only minimally achieved; above all, this approach does not yield the expected benefits for local communities. This does not mean, however, that the mere fact of initiating these practices is not an opportunity for developing and testing new forms of territorial governance.

This is a crucial point. In some cases, in order to start an ecomuseum process in a territory it is necessary to adopt measures that are implemented by outsiders, however it is also important to consider how to avoid forms of exploitation: giving money to reduce poverty must not become a way of subjugating the local community entirely to the will of the government or of external investors. Instead, attempts to alleviate poverty through measures promoted by outsiders must be accompanied by educational programs that allow for collaboration with local communities. These programs should highlight the value of the communities' specific cultural qualities, thus enabling them to promote measures to enhance their local heritage in the future.

In light of the above, and after this initial analysis of ecomuseums in China, we are in the position to make the following recommendations. The first concerns the role of external (i.e. non-local) players as promoters of ecomuseum projects; the second concerns the importance of dialectic interactions between local communities and places; the last is about the dimension of ongoing change.

The first recommendation is a response to the following question: to what extent can an ecomuseum project promoted by external players bring benefits to a local community even if the latter is not leading the ecomuseum project? We suggest that, when promoted by external players, ecomuseums should take on the role of encouraging participation among the local community. As seen in China, not all local communities are ready to play leading parts in valorizing their local heritage; an ecomuseum project implemented by external players should therefore first and foremost determine the state of the location and only then decide on the type of project to develop. One possibility is that the outside investor, during initial analysis for an ecomuseum project, could assign the territory to one of three categories: territories whose improvement first requires projects in the physical surroundings; territories whose local community needs to be helped to understand its potential role (recognized as part of the intangible heritage); territories where the local community is already active and able to preserve and enhance the local cultural patrimony. 
In China, territories have often been activated by firstly improving the state of the physical surroundings. What has been missing is a clear attempt by external players to get the local community more involved, more aware, and therefore better equipped to later autonomously pursue activities to enhance their local heritage.

It is this latter point that requires a change in the governance of these projects. It is necessary to make external players more aware of their role, which is not merely one of making territories more attractive to tourists, but involves working with the local community to raise their awareness both of their potential for action and of the value of their territory.

The second recommendation is that the theoretical debate should place greater emphasis on the importance of interaction between local communities and their surroundings. For a long time, the preservation and enhancement of local heritage was considered something that only concerned external surroundings, whether tangible or intangible resources. Later, however, the importance of local communities' role emerged: it became seen as crucial for the preservation of local heritage. It is important to highlight that the relationship between these two poles is dialectic and that paying attention to local communities' sense of place does not mean giving excessive value to that place itself, but rather foregrounding the relationship between communities and the places they inhabit.

Recognition that the relationship between local heritage and local community is dialectical also allows us to add our support to another key principle of ecomuseums, and that is the principle of ongoing change: if the relationship is dynamic then there is no risk, a few years down the line, of seeing an ecomuseum turn into a traditional museum or becoming part of a process of museification $^{1}$. The local community changes, and with it so does the way in which local heritage resources are managed.

To conclude, we merely want to stress how research carried out in China has clearly exposed a gap between discourse and practice in the ecomuseum debate. If ecomuseum principles are to be fulfilled, then it is crucial to close this gap, moving beyond the approach consolidated in the ecomuseum debate and creating openings for new interpretative frames ${ }^{2}$.

\section{Bibliography}

Agnew N., Demas M., \& Sullivan S., The development of the China Principles: A Review to Date in: International Principles and Local Practice of Cultural Heritage Conservation: Conference Proceedings, National Heritage Center of Tsinghua University, ICOMOS China, Beijing 2014, pp. 11-30.

Berkes F., Evolution of co-management: Role of knowledge generation, bridging organizations and social learning in: Journal of Environmental Management 90, 5/2009, pp. 1692-1702.

\footnotetext{
${ }^{1}$ See G. Corsane \& al., Ecomuseum Evaluation ..., p. 105.

${ }^{2}$ Compliance with Ethical Statements. Funding: This study was supported by the Hanban Program Confucius Institute Headquarters and by the Fundamental Research Funds for the Central Universities. The project number is 20720181075 . Conflict of Interest: The authors declare that they have no conflict of interest.
} 
Bennett T., Civic laboratories: museums, cultural objecthood and the governance of the social in: Cultural studies 19, 5/2005, pp. 521-547.

Benoist L., Musées et muséologie, PUF, Paris 1971.

Borrelli N. \& Davis P., How culture shapes nature: Reflections on ecomuseum practices in: Nature and Culture 7, 1/2012, pp. 31-47.

Bourdieu P. \& Wacquant L. J., Réponses: pour une anthropologie réflexive, Seuil, Paris 1992.

Buttimer A. \& Seamon D., The human experience of space and place. London: Croom Helm in: Transactions, Institute of British Geographers NS 18, 1980, pp. 460-480.

Cars G. \& al., Urban governance, institutional capacity and social milieu, Routledge, London 2017.

Chio J., A landscape of travel. The work of tourism in rural ethnic China, University of Washington Press, Washington 2014.

Coaffee J. \& Healey P., 'My voice: My place': Tracking transformations in urban governance in: Urban studies 40, 10/2003, pp. 1979-1999.

Corsane G., From 'outreach' to 'inreach': How ecomuseum principles encourage community participation in museum processes in: Communication and exploration: Guiyang, China, (eds.) Su Dongai \& J. Zhang, Zijin City Publishing House, Beijing 2005, pp. 109-124.

Corsane G., Using ecomuseum indicators to evaluate the Robben Island Museum and World Heritage Site in: Landscape Research 31, 4/2006, pp. 399 418.

Corsane G. \& al., Ecomuseum Evaluation: Experiences in Piemonte and Liguria, Italy in: International Journal of Heritage Studies 13, 2/2007, pp. 101116.

Corsane G. \& al., Ecomuseum Performance in Piemonte and Liguria, Italy: The Significance of Capital in: International Journal of Heritage Studies 13, 3/2007, pp. 224-239.

Corsane G. \& Holleman W., Ecomuseums: A Brief Evaluation in: Museums and the Environment, (ed.) R. de Jong, South African Museums Association, Pretoria 1993, pp. 111-125.

Davis P., Ecomuseums: A Sense of Place, Leicester University Press, London 1999.

Davis P., New Museologies and the Ecomuseum in: Research Companion to Heritage and Identity, (eds.) B. Graham \& P. Howard, Ashgate, London 2008, pp. 397-414.

Davis P., Ecomuseums: A Sense of Place, [2 ${ }^{\text {nd }}$ ed.] A\&C Black, London 2011.

GCI (Getty Conservation Institute), China Principles (1997-2015): Application of the China Principles at Maogao Grottoes, Los Angeles, page updated on August 2019 [available at http://www.getty.edu/conservation/our_projects/ field_projects/china/app_mogao.html, retrieved Oct. 2, 2019].

Goulding C., The commodification of the past, postmodern pastiche, and the search for authentic experiences at contemporary heritage attractions in: European Journal of Marketing 34, 7/2000, pp. 835-853.

Graburn N. \& Jin L., Tourism and Museums in China in: Asian Journal of Tourism Research 2, 1/2017, pp. 1-34. 
Hahn T., Olsson P., Folke C., \& Johansson K., Trust-building, knowledge generation and organizational innovations: the role of a bridging organization for adaptive comanagement of a wetland landscape around Kristianstad, Sweden in: Human ecology 34, 4/2006, pp. 573-592.

Hamrin O. \& Mats H., The Ecomuseum Bergslagen Falun: Ekomuseum Bergslagen in: Nordisk Museologi 2, 1996, pp. 27-34.

Hillier J. \& Rooksby E. (eds.), Habitus: A sense of place, Ashgate, London 2005.

Hu C., Ecomuseums in Guizhou: Practice and Exploration in: Communication and Exploration: International Forum of Ecomuseums 9, 2005, pp. 15-18.

Hu C., Liuzhi Yuanze yu Minzu Wenhua Baohu [Liuzhi Principle and the Protection of Ethnic Culture] in: Zhongguo Wenwu Bao [Chinese Cultural Relics News] (2005-01-21), 2005, p. 5.

Hubert F., Ecomuseums in France: Contradictions and Distortions in: Chinese Museum 37, 1986, pp. 78-82.

Hudson K., Museums of Influence, Cambridge University Press, Cambridge 1987.

Hudson K., The Dream and the Reality in: Museums Journal 92, 4/1992, pp. $27-31$.

Hudson K., Ecomuseums Become More Realistic in: Nordisk Museologi 7, 2/1996, pp. 11-20.

ICOMOS China, Zhongguo Wenwu Guji Baohu Zhunze [Principles for the Conservation of Heritage Sites in China], The Getty Conservation Institute, Los Angeles 2002 [available at http://www.getty.edu/conservation. publications_resources/pdf_publications/pdf/china_prin_heritage_sites.pd f, retrieved Oct. 1, 2019].

McCall V. \& Gray C., Museums and the 'new museology': theory, practice and organisational change in: Museum Management and Curatorship 29, 1/2014, pp. 19-35.

Mensch van P., Towards a methodology of museology, University of Zagreb, Zagreb 1992.

Navajas O., New Common Perspectives for Ecomuseums, Community Museums, and Cultural Landscapes in: Ecomuseums and cultural landscapes. State of the art, (ed.) R. Riva, Studi e progetti, Milano 2017.

Newton J. \& Franklin A., Delivering sustainable communities in China: using a sustainable livelihoods framework for reviewing the promotion of "ecotourism" in Anji in: Local Environment 16, 8/2011, pp. 789-806.

Nguyen T. H. H. \& Cheung C., Authenticity and commodification of Hong Kong heritage tourism in: Proceedings of Invtur 2017 Conference. Co-creating the future of tourism, University of Aveiro Press, Aveiro 2017 [available at https://core.ac.uk/download/pdf/154425375.pdf, retrieved Oct. 10, 2019].

Nitzky W., Mediating Heritage Preservation and Rural Development: Ecomuseum Development in China in: Urban Anthropology 41, 2-3-4/2012, pp. 367-417.

Nitzky W., Ecomuseums with Chinese Characteristics: The Politics of Safeguarding Living Heritage in: Proceedings of Ecomuseums $2012-1^{\text {st }}$ International Conference on Ecomuseums, Community Museums and 
Living Communities, (eds.) S. Lira, R. Amoêda, C. Pinheiro, P. Davis, M. Stefano \& G. Corsane, Green Lines Institute for Sustainable Development, Barcelos 2012, pp. 259-270.

Nitzky W., Community Empowerment at the Periphery? Participatory Approaches to Heritage Protection in Guizhou, China in: Cultural Heritage Politics in China, (eds.) T. R Blumenfield \& H. Silverman, Springer, New York 2013, pp. 205-234.

Olsson P., Folke C., Galaz V., Hahn T., \& Schultz L., Enhancing the fit through adaptive co-management: creating and maintaining bridging functions for matching scales in the Kristianstads Vattenrike Biosphere Reserve, Sweden in: Ecology and Society 12, 1/2007 [available at https://www.ecology andsociety.org/vol12/iss1/art28/, retrieved Oct. 10, 2019].

Pan S., Shengtai Bowuguan ji qi zai Zhongguo de Fazhan: Lishi xing Guancha yu Sikao [Ecomuseum and Its Development in China: Chronicle Observation and Perspectives] in: Chinese Museum Z1, 2011, pp. 24-33.

Pan S., Di San Dai Shengtai Bowuguan yu Anji Shengtai Bowuguan Qun Jianshe de Lilun Sikao [Theoretical Discussion on the Third-Generation Ecomuseums and the Construction of Anji Ecomuseum Cluster] in: Southeast Culture 236, 2013, pp. 86-93.

Pan S., Self-cognition and Self-education at Ecomuseum: From 'Information Center' to 'Cognition Center' in: Science Education and Museums 1, 2015, pp. 35-38.

Plummer R., Armitage D., \& de Loë R., Adaptive comanagement and its relationship to environmental governance in: Ecology and Society 18, 1/2013 [available at https://www.ecologyandsociety.org/vol18/iss1/art21/, retrieved Oct. 5, 2019].

Primo J., Museus Locais e Ecomuseologia: Estudos do Projeto para o Ecomuseu da Murtosa in: Cadernos de Museologia 30, 2008 [available at https://revistas.ulusofona.pt/index.php/cadernosociomuseologia/issue/vie $\mathrm{w} / 47$, retrieved 10.10.2019].

Rivard R., Opening up the Museum or Toward a New Museology: Ecomuseums and "Open" Museums, Québec 1984 [copy of manuscrit held at the Documentation Centre, Direction des Musées, Paris].

Rivard R., Museums and ecomuseums: questions and answers in: Økomuseumsboka-Identitet, Økologi, Deltakelse, (eds.) J. Gjestrum \& R. Maure, Norsk ICOM, Tromsø 1988, pp. 123-128.

Rivière G. H., The Ecomuseum: An Evolutive Definition in: Museum International 37, 4/1985, pp. 182-184 [Chinese text transl. by Meng Qing-long].

Schultz L., Folke C., \& Olsson P., Enhancing ecosystem management through social-ecological inventories: lessons from Kristianstads Vattenrike, Sweden in: Environmental Conservation 34, 2/2007, pp.140-152.

Shepherd R., Commodification, culture and tourism in: Tourist Studies 2, 2002, pp. 183-201.

Sofield T. H. B. \& Li F. M., Tourism Development and Cultural Policies in China in: Annals of Tourism Research 25, 2/1998, pp. 362-392.

Su D., Zhongguo Shengtai Bowuguan de Daolu [Chinese Ecomuseum: The Path of Development] in: Chinese Museum 22, 3/2005, pp. 14-16. 
Stead D. \& Meijers E., Spatial Planning and Policy Integration: Concepts, Facilitators and Inhibitors in: Planning Theory \& Practice 10, 3/2009, pp. 317-332.

Tuan Y.-F., Space and Place the Perspective of Experience, University of Minnesota Press, Minneapolis 1977.

UNWTO, UNWTO and China Organize First World Conference on Tourism for Development, Beijing 2016 [available at http://media.unwto.org/pressrelease/2016-02-24/unwto-and-china-organize-first-world-conferencetourism-development, retrieved Oct. 1, 2019].

Varine de H., Ecomuseum: The word and beyond in: Chinese Museum 37, 1986, pp. 76-77.

Varine de H., Rethinking the museum concept in: Økomuseumsboka-identitet, økologi, deltakelse, (eds.) J. A. Gjestrum \& M. Maure, ICOM, Tromsø 1988, pp. 33-40.

Vergo P., The New museology, Reaktion Books, London 1989.

Westley F., Tjornbo O., Schultz L., Olsson P., Folke C., Crona B. \& Bodin Ö., A theory of transformative agency in linked social-ecological systems in: Ecology and Society 18, 3/2013 [available at https://www.ecologyand society.org/vol18/iss3/art27/, retrieved Oct. 5, 2019].

Wu W., Cong Minzu Shengtai Bowuguan Kan Guangxi Minzu Shengtai Wenhua de Baohu yu Chuancheng [The Protecting and Passing of Ethnic Cultural Resources in Guangxi] in: Guangxi Minzu Yanjiu [Guangxi Minzu Studies] 88, 2/2007, pp. 199-205. 
Table 1. The list of Ecomuseums in China. (Source: the authors) ${ }^{1}$

\begin{tabular}{|c|c|c|c|c|c|}
\hline Region & Name & City/County & $\begin{array}{l}\text { Ethnic } \\
\text { Group }\end{array}$ & Opened & Management \\
\hline \multirow{8}{*}{$\begin{array}{l}\text { 1. Guizhou } \\
\text { Province }\end{array}$} & $\begin{array}{l}\text { Suoga Miao } \\
\text { Ecomuseum }\end{array}$ & $\begin{array}{l}\text { Liupanshui } \\
\text { Municipality }\end{array}$ & Miao & 1998 & \multirow{4}{*}{$\begin{array}{l}\text { Sino-- } \\
\text { Norwegian } \\
\text { collaborative } \\
\text { Funds and } \\
\text { Supervise }\end{array}$} \\
\hline & $\begin{array}{l}\text { Zhenshan } \\
\text { Buyi } \\
\text { Ecomuseum }\end{array}$ & Guiyang & Buyi & 2002 & \\
\hline & $\begin{array}{l}\text { Longli } \\
\text { Ancient Town } \\
\text { Ecomuseum }\end{array}$ & $\begin{array}{l}\text { Prefecture of } \\
\text { Miao and } \\
\text { Dong People } \\
\text { Of Southeast } \\
\text { Guizhou }\end{array}$ & Han & 2004 & \\
\hline & $\begin{array}{l}\text { Tang'an } \\
\text { Dong } \\
\text { Ecomuseum }\end{array}$ & $\begin{array}{l}\text { Prefecture of } \\
\text { Miao and } \\
\text { Dong People } \\
\text { Of Southeast } \\
\text { Guizhou }\end{array}$ & Dong & 2005 & \\
\hline & $\begin{array}{l}\text { Dimen Dong } \\
\text { Ecomuseum }\end{array}$ & $\begin{array}{l}\text { Prefecture of } \\
\text { Miao and } \\
\text { Dong People } \\
\text { Of Southeast } \\
\text { Guizhou }\end{array}$ & Dong & 2004 & \multirow{3}{*}{$\begin{array}{l}\text { Private } \\
\text { enterprises or } \\
\text { agencies. } \\
\text { Most of them } \\
\text { are not official } \\
\text { and the statuses } \\
\text { are unclear. }\end{array}$} \\
\hline & $\begin{array}{l}\text { Xijiang } \\
\text { Thousand } \\
\text { Miao Houses } \\
\text { Ecomuseum }\end{array}$ & $\begin{array}{l}\text { Prefecture of } \\
\text { Miao and } \\
\text { Dong People } \\
\text { Of Southeast } \\
\text { Guizhou }\end{array}$ & Miao & 2005 & \\
\hline & $\begin{array}{l}\text { Zenlei Shui } \\
\text { Ecomuseum }\end{array}$ & $\begin{array}{l}\text { Prefecture of } \\
\text { Buyi and } \\
\text { Miao People } \\
\text { of South } \\
\text { Guizhou }\end{array}$ & Shui & 2008 & \\
\hline & $\begin{array}{l}\text { Guizhou Tea } \\
\text { Culture } \\
\text { Ecomuseum }\end{array}$ & Zunyi & & 2013 & $\begin{array}{l}\text { Meitan County } \\
\text { Bureau of } \\
\text { Culture, Sports, } \\
\text { Broadcasting } \\
\text { and Tourism }\end{array}$ \\
\hline $\begin{array}{l}\text { 2. Guangxi } \\
\text { Zhuang } \\
\text { Autonomous } \\
\text { Region }\end{array}$ & $\begin{array}{l}\text { White- } \\
\text { trousers Yao } \\
\text { Ecomuseum } \\
\text { of Nandan }\end{array}$ & Hechi & Yao & 2004 & $\begin{array}{l}\text { Guangxi Minzu } \\
\text { Museum } \\
\&\end{array}$ \\
\hline
\end{tabular}

${ }^{1}$ In W. Nitzky, Mediating Heritage Preservation and Rural Development ..., we also found information about ecomuseums in Shanxi, Anhui, and Fujian, but we were not able to collect information in the field. 


\begin{tabular}{|c|c|c|c|c|c|}
\hline & $\begin{array}{l}\text { Dong } \\
\text { Ecomuseum } \\
\text { of Sanjiang }\end{array}$ & Liuzhou & Dong & 2004 & $\begin{array}{l}\text { Department of } \\
\text { Culture of } \\
\text { Guangxi }\end{array}$ \\
\hline & $\begin{array}{l}\text { Zhuang } \\
\text { Ecomuseum } \\
\text { of Jingxi }\end{array}$ & Baise & Zhuang & 2005 & $\begin{array}{l}\text { Zhuang } \\
\text { Autonomous } \\
\text { Region }\end{array}$ \\
\hline & $\begin{array}{l}\text { Hakka } \\
\text { Ecomuseum } \\
\text { of Hezhou }\end{array}$ & Hezhou & $\begin{array}{l}\text { Hakka } \\
\text { (Han) }\end{array}$ & 2007 & \\
\hline & $\begin{array}{l}\text { Black-clothes } \\
\text { Zhuang } \\
\text { Ecomuseum } \\
\text { of Napo }\end{array}$ & Baise & Zhuang & 2008 & \\
\hline & $\begin{array}{l}\text { Ecomuseum } \\
\text { in Lingchuan }\end{array}$ & Guilin & Han & 2009 & \\
\hline & $\begin{array}{l}\text { Jing } \\
\text { Ecomuseum } \\
\text { of Dongxing }\end{array}$ & $\begin{array}{l}\text { Fangcheng } \\
\text { Harbor }\end{array}$ & Jing & 2009 & \\
\hline & $\begin{array}{l}\text { Miao } \\
\text { Ecomuseum } \\
\text { of Rongshui }\end{array}$ & Liuzhou & Miao & 2009 & \\
\hline & $\begin{array}{l}\text { Zhuang } \\
\text { Ecomuseum } \\
\text { of Longsheng }\end{array}$ & Guilin & Zhuang & 2010 & \\
\hline & $\begin{array}{l}\text { Aoyao } \\
\text { Ecomuseum } \\
\text { of Jinxiu }\end{array}$ & Laibin & Yao & 2011 & \\
\hline & $\begin{array}{l}\text { Zhanglang } \\
\text { Bulang } \\
\text { Ecomuseum }\end{array}$ & $\begin{array}{l}\text { Xishuang } \\
\text { Banna, } \\
\text { Yunnan }\end{array}$ & Bulang & 2006 & \\
\hline 3. Yunnan & Baka $^{1}$ & & Jinuo & 2002 & \\
\hline Province & Xianrendong $^{1}$ & & $\mathrm{Yi}$ & 2002 & \\
\hline & Heshun $^{1}$ & & Han & 2002 & \\
\hline & Yuehu $^{1}$ & & $\mathrm{Yi}$ & 2002 & \\
\hline & Nanjian $^{1}$ & & Dai & 2002 & \\
\hline $\begin{array}{l}\text { 4. Inner } \\
\text { Mongolia }\end{array}$ & $\begin{array}{l}\text { Aolun Sumu } \\
\text { Mongolia } \\
\text { Ecomuseum }\end{array}$ & $\begin{array}{l}\text { Baotou, } \\
\text { Inner } \\
\text { Mongolia }\end{array}$ & Mongolia & 2007 & $\begin{array}{l}\text { Local } \\
\text { government }\end{array}$ \\
\hline $\begin{array}{l}\text { 5. Hunan } \\
\text { Province }\end{array}$ & $\begin{array}{l}\text { Jiangyong } \\
\text { Nüshu Script } \\
\text { Ecomuseum }\end{array}$ & $\begin{array}{l}\text { Yongzhou, } \\
\text { Hunan }\end{array}$ & $\begin{array}{l}\text { Han } \\
\text { (female) }\end{array}$ & 2010 & $\begin{array}{l}\text { Private } \\
\text { enterprise }\end{array}$ \\
\hline
\end{tabular}

\footnotetext{
${ }^{1}$ Source: P. Davis, Ecomuseums: A Sense of Place, [2 ${ }^{\text {nd }}$ ed.], p. 239.
} 


\begin{tabular}{|c|c|c|c|c|c|}
\hline $\begin{array}{l}\text { 6. Zhejiang } \\
\text { Province }\end{array}$ & $\begin{array}{l}\text { Anji Ecology } \\
\text { Museum } \\
\text { Group, } \\
\text { including: } \\
1 \text { Centre } \\
\text { museum, } \\
13 \text { Theme } \\
\text { museums, } \\
26 \text { Village } \\
\text { museums; } \\
\text { number } \\
\text { changes over } \\
\text { time }\end{array}$ & $\begin{array}{l}\text { Anji, } \\
\text { Huzhou }\end{array}$ & $\begin{array}{l}\text { Han; } \\
\text { She }\end{array}$ & 2012 & $\begin{array}{l}\text { County } \\
\text { government; } \\
\text { State } \\
\text { Administration } \\
\text { of Cultural } \\
\text { Heritage }\end{array}$ \\
\hline
\end{tabular}

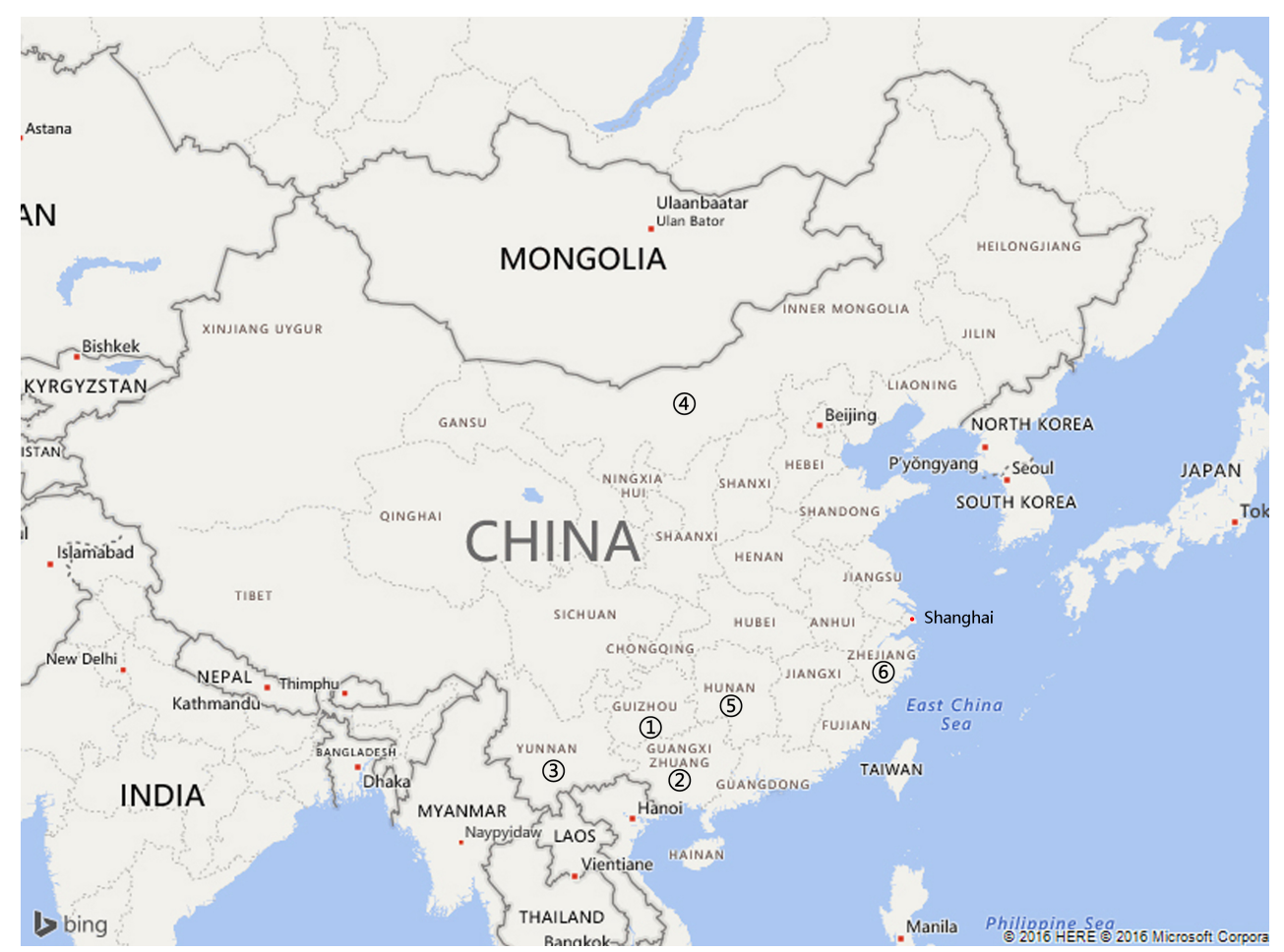

Fig. 1. Map of regions with established ecomuseums:

1. Guizhou

2. Guangxi

3. Yunnan

4. Inner Mongolia

5. Hunan

6. Zhejiang.

(Source: Bing map with the authors' elaborations) 


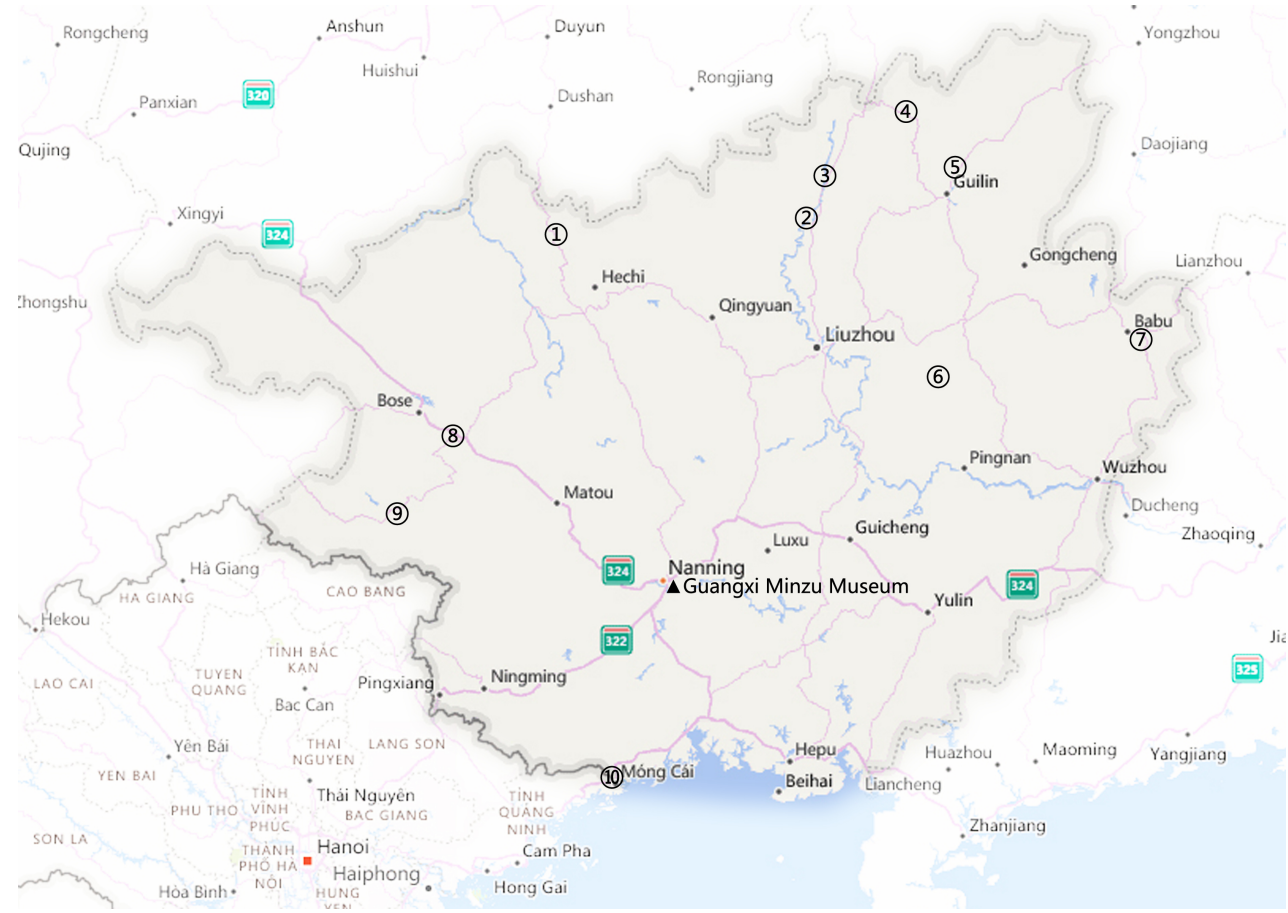

Fig. 2. Map of ecomuseums in Guangxi:

1. White-trousers Yao Ecomuseum of Nandan

2. Miao Ecomuseum of Rongshui

3. Dong Ecomuseum of Sanjiang

4. Zhuang Ecomuseum of Longsheng

5. Ecomuseum of Lingchuan

6. Aoyao Ecomuseum of Jinxiu

7. Hakka Ecomuseum of Hezhou

8. Black-clothes Zhuang Ecomuseum of Napo

9. Zhuang Ecomuseum of Jingxi

10. Jing Ecomuseum of Dongxing.

(Source: Bing map with authors elaborations) 


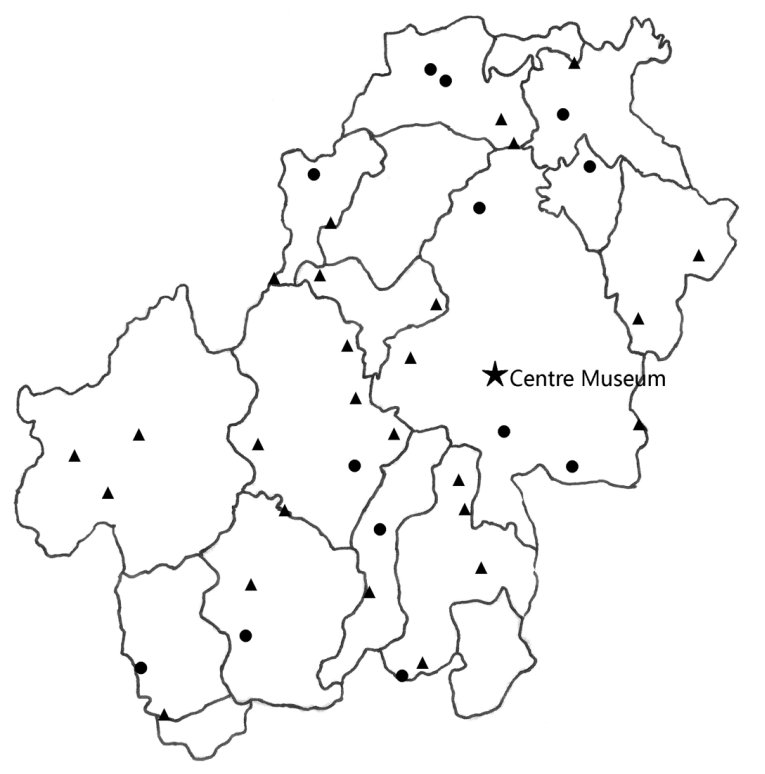

Fig. 3. Map of Anji Ecology Museum Group in Anji County.

Illustration:

$\star$ centre museum

- theme museums

$\Delta$ village museums.

(Source: Produced by Rongling Ge) 


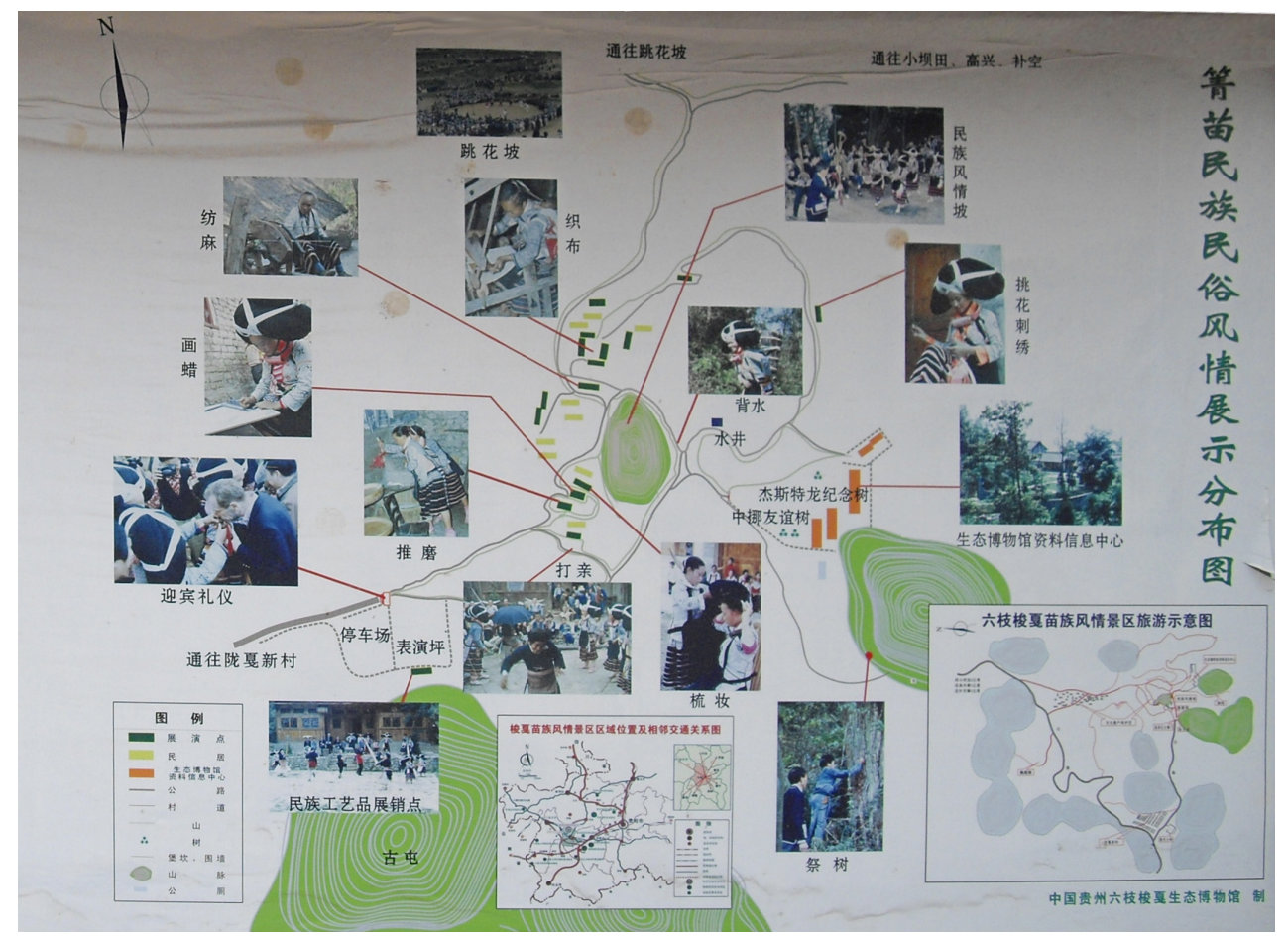

Fig. 4. Visitor map of Suoga Ecomuseum.

(Source: Collected from the ecomuseum by Rongling $\mathrm{Ge}$ ) 


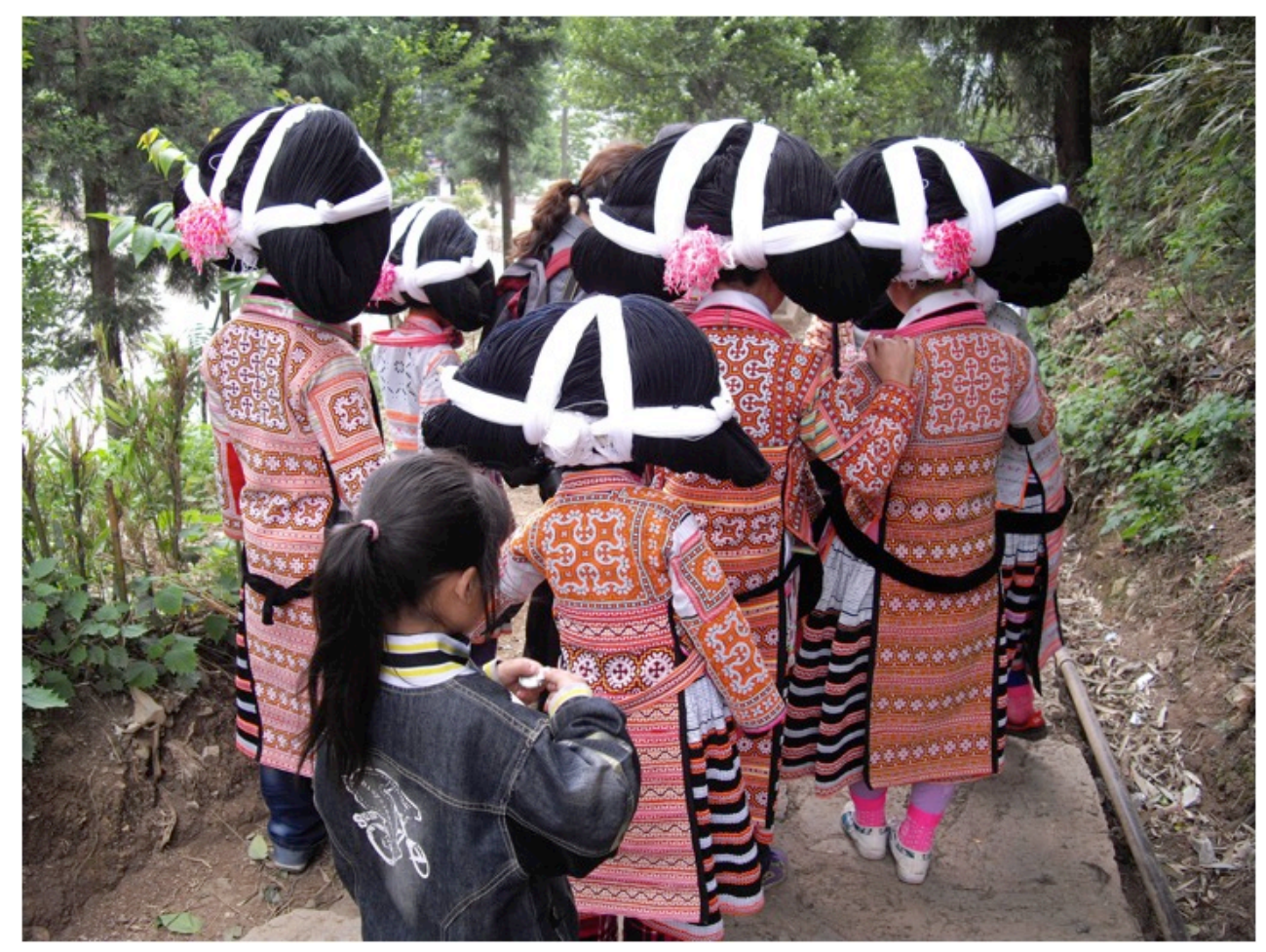

Fig. 5. Local girls modelling the clothing and headdress of the Longhorn Miao in Suoga Ecomuseum.

(Source: Photograph by Rongling Ge) 